\title{
Erratum: Parvalbumin-expressing interneurons coordinate hippocampal network dynamics required for memory consolidation
}

Nicolette Ognjanovski, Samantha Schaeffer, Jiaxing Wu, Sima Mofakham, Daniel Maruyama, Michal Zochowski \& Sara J. Aton

Nature Communications 8:15039 doi: 10.1038/ncomms15039 (2017); Published 6 Apr 2017; Updated 6 Jul 2017

The original version of the Supplementary Information attached to this Article did not contain Supplementary Figures 11-16 and Supplementary References. The HTML has now been updated to include a corrected version of the Supplementary Information file.

Open Access This article is licensed under a Creative Commons Attribution 4.0 International License, which permits use, sharing, adaptation, distribution and reproduction in any medium or format, as long as you give appropriate credit to the original author(s) and the source, provide a link to the Creative Commons license, and indicate if changes were made. The images or other third party material in this article are included in the article's Creative Commons license, unless indicated otherwise in a credit line to the material. If material is not included in the article's Creative Commons license and your intended use is not permitted by statutory regulation or exceeds the permitted use, you will need to obtain permission directly from the copyright holder. To view a copy of this license, visit http://creativecommons.org/licenses/by/4.0/

(C) The Author(s) 2017 